\title{
Effects of Drug Addiction and Abuse on Academic Performance of Students Within the Age of 14-30 Years
}

\author{
Md. Aminur Rahaman ${ }^{1 *}$, Hamida Khanum ${ }^{2,3}$ and Amina Akter ${ }^{4 *}$ \\ ${ }^{1}$ Quality Control Department (Sterile), Beximco Pharmaceuticals Ltd. Tongi, Gazipur, Dhaka, Bangladesh \\ ${ }^{2}$ Department of Zoology, University of Dhaka, Dhaka, Bangladesh \\ ${ }^{3}$ American International University, Bangladesh, Dhaka, Bangladesh \\ ${ }^{4}$ Msc in Applied Economics, Department of Economics and Social Science, BRAC University, Bangladesh \\ *Corresponding authors: Md Aminur Rahman, Quality Control Department (Sterile), Beximco Pharmaceuticals Ltd. Tongi, Gazipur, \\ Dhaka, Bangadesh \\ Amina Akter, Msc in Applied Economics, Department of Economics and Social Science, BRAC University, Bangladesh
}

\begin{tabular}{|c|}
\hline ARTICLE INFO \\
\hline Received: 㗀 December 02, 2021 \\
\hline Published: December 09, 2021 \\
\hline $\begin{array}{l}\text { Citation: Md. Aminur Rahaman, Hamida } \\
\text { Khanum, Amina Akter. Effects of Drug } \\
\text { Addiction and Abuse on Academic Per- } \\
\text { formance of Students Within the Age } \\
\text { of 14-30 Years. Biomed J Sci \& Tech Res } \\
40(3)-2021 \text {. BJSTR. MS.ID.006454. }\end{array}$ \\
\hline
\end{tabular}

Keywords: Drug Addiction; Abuse; Students; Academic Performance

\begin{abstract}
Drug abuse and addiction also called substance or chemical abuse, is a disorder that is characterized by a destructive pattern of applying drugs thereby leading to significant problems or distress. This phenomenon cuts across every strata of human society but more dominant (37.76\%) among the youths (14-18 years). The study, analytical research design, and simple random sampling have been followed also explores data from both primary and secondary sources. The present findings suggest that Yaba (31.47\%) was major abused drugs in the age between $14-30$ years. (31.47\%). The findings on the extent to which several factors influence students to abuse drugs such as mostly peer pressure $(27.27 \%$, frustration, mental stress relief, curiosity, buildup self-esteem \& ability to increase performance, sense of euphoria. Most of the drug addicts think that peer pressure and frustration are major cause of drug addiction. Due to drug addiction many physiological consequences have been faced by the student's likely headache, memory loss, gastritis, highest was insomnia (32.87\%), bad tempered and instability. Drug addiction effected on academic performance resulted severe grade decades, drop out, low concentration span (41.26\%), discontinuation of academic career, lack of interest in extra curriculum activities and strained relationship with other students. So the research concludes and recommends that parents and public enlighten should be carried out periodically on the dangers of drug addiction. While the regulatory bodies be strengthened to carry out their functions.
\end{abstract}

\section{Introduction}

Drugs are substances that influence the physical and mental state of persons essentially and destructively any substance that can prompt compulsion, abuse and reliance is a medication [1]. The level of enslavement for drugs increments with every day of utilization. On the off chance that drugs are not accessible, the patient shows discriminating withdrawal manifestations when prompt restorative consideration is expected to forestall physical and mental decay, even demise (Psychology) [2]. World Health Organization (WHO 2002 and 2003) characterizes tranquilize as a compound substance planned for indicative, restorative or palliative utilization or for altering physiological elements of man and creature, [south_Asia_Regional_Profile_Sept_2005/08_ bangladesh.pdf]. Opium has been used for medical purposes since 3500 years ago. Morphine was discovered in 1806 and codeine in 1832. Cocaine was extracted from leaves of coca plant in 1860. 
Injecting morphine and heroin was expanded at the beginning of $20^{\text {th }}$ century [3-5]. Addiction to drugs is one of the saddest tragedies of modern man which threatens his life. Despite this, unfortunately tendency toward these deadly substances, especially opiate substances, is daily increasing, especially among adolescents [6]. Drug consumption in Iran has started thousands of years ago. Over the last century, expanded consumption of heroin and other narcotics, especially ecstasy and cocaine during past decades has complicated the condition of drug abuse in our country [3,7-10].

Studies conducted by United Nations show that more than $180,000,000$ people in the world are addicted to drugs [11-14]. On the other hand, quitting addiction is complicated and difficult and is not successful most of the times [15]. Hashish is the most prevalent drug being used in America and many other countries. In North America, south and center of America most problems occur due to consumption of cocaine [16]. Most used drugs in Europe are cannabis, heroin, amphetamine and hallucinatory, besides to ecstasy. In most Asian countries most problematic drugs are cannabis and opiate substances $[17,18]$. According to a United Nations Office on Drugs and Crime (UNODC) Report (2005), about 200 million people, or 5 percent of the world's population age between 15 and 65 have used drugs at least once in the last 12 months. Likewise, according to the World Drug (2005) reported that, the use of illicit drugs in all Nations has increased in recent years. For most of Europe and Asia, opiates accounted for 62 percent of all drug treatment sought in 2003. A survey in the Czech Republic showed that $37 \%$ of new drug users were teenagers between 15 and 19 years old. In Egypt, drug use - in particular heroin use - is becoming a serious problem and nearly 6 percent of secondary and tertiary school students admit to having experimented with drugs [15]. The history of human race has also been the history of drug abuse [19]. History tells us that the Chinese used Opium as a cure of dysentery before the $18^{\text {th }}$ century. European countries such as Britain and Holland were known to exchange opium growth in their colonies for tea and silk with China [20].

\section{State of Drug Abuse and Drug Addiction Global Perspective}

Drug abuse is a global problem that poses a great danger to the lives of individuals, society and political stability and security in many countries [United Nations 1995]. According to the United Nations (2005), the use of illicit drugs has increased throughout the world and the major world trend is the increasing availability of many kinds of drugs among ever widening spectrum of consumers [21-23]. A study carried out by the London School of Economics in 1980, on students learning behavior revealed a relationship between drug abuse addiction and poor academic results [Otieno et al. 1994]. The continent, over recent years has experienced an upsurge in the production, distribution and consumption of drugs with the youth and young adults being most affected [24-26]. In Ethiopia, it is reported that 82 per cent of the street children in Addis Ababa use some kind of a drug [27-29]. According to the United Nations (UN) statistics (2013), 37,000 people in Africa die annually from diseases associated with drug abuse.

\section{State of Drug Abuse and Drug Addiction: Bangladesh Perspective}

Adolescents, especially those who are socially weak, may choose drug abuse as a means to integrate themselves into a peer group, and thereby increase self-esteem and decrease anxiety [30]. They feel failure and frustrated. Parental factors exert significant influence on the overall development of the child. It is not only impairing public health, but also corrupting institutions, retarding socio-economic development, and threatening political stability and, in some cases, impacting state security [31-33]. Due to drug addiction, criminal activities are increasing with alarming rate in all over the country. Especially in urban areas like Dhaka, Chittagong, Rajshahi, Khulna, Barisal and Sylhet. According to Family Health International (FHI) about 50 lac people of Bangladesh are drug addicted [34]

\section{Materials and Methods}

The present study designed as descriptive, qualitative and cross-sectional type, conducted in various Rehabilitation centers located in Dhaka city. The study population was consist of students in Rehabilitation center aged 14 to 30 years old. Random sampling technique (Probability sampling) was applied for determining sample size and data collection. Data was collected by a self-administered questionnaire, which was pre-tested. The investigation was conducted upon 143 students in various rehab center located in the Dhaka city located in the Dhaka city. The questionnaire and findings are based on the objectives and variables. Data was processed and analyzed using Microsoft Excel and SPSS version 21.00 .

\section{Ethical Considerations}

Approval letter for conducting research was taken from American International University- Bangladesh (AIUB) during MPH courses.

\section{Results and Findings}

In the present study, 34.97 percent of the participants were 14-18 year olds, 38.46 percent of the participants were 19-23 year olds, 18.18 percent were 24-27 year olds and 8.39 percent were 28-30 year olds (Figure 1), 79.72 percent of the participants were males, and 20.28 percent of the participants were females. Showed that 15.38 percent of the participants were below SSC, 29.37 percent passed SSC, 34.97 percent passed HSC, 16.08 percent passed bachelors and 4.20 percent passed masters (Figure 2). In 
the present study, 62.94 percent participants were lived in urban area whereas, 37.06 percent were lived in rural area, 62.94 percent participants were lived in nuclear family and 37.06 percent were lived in join family. The analysis indicates that $37.76 \%$ of the respondents' abused drugs for the first time at the age of 14-18 years old, $33.57 \%$ of the respondents abused drugs for the first time at the age of 19-23 years old, $20.28 \%$ were abused drugs for the first time at the age of 24-27 years old and $8.39 \%$ were abused drugs for the first time at the age of 28-30 years old.

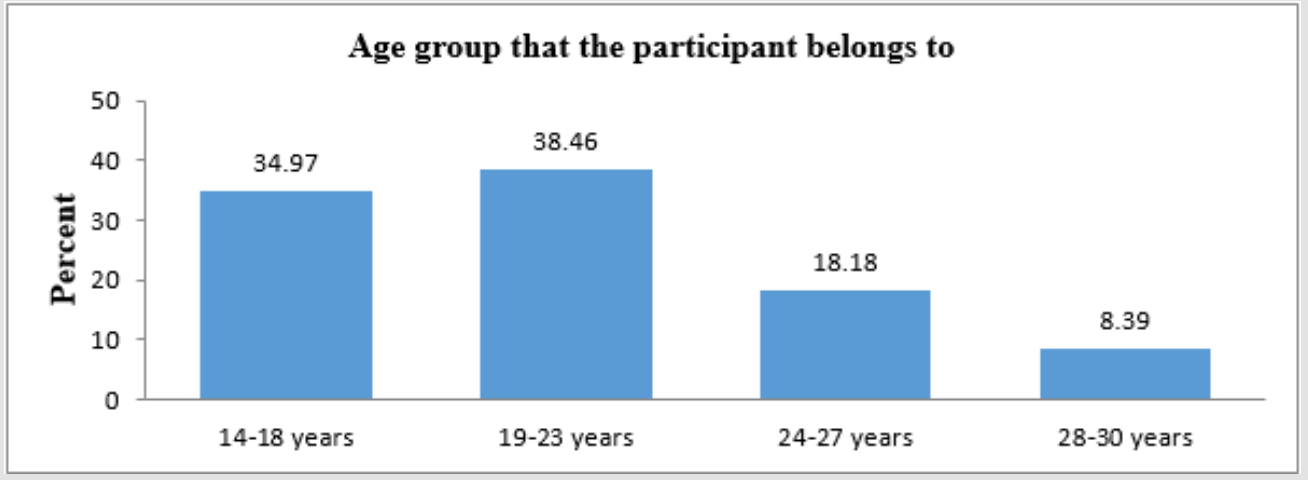

Figure 1: Distribution of the participants by their age.

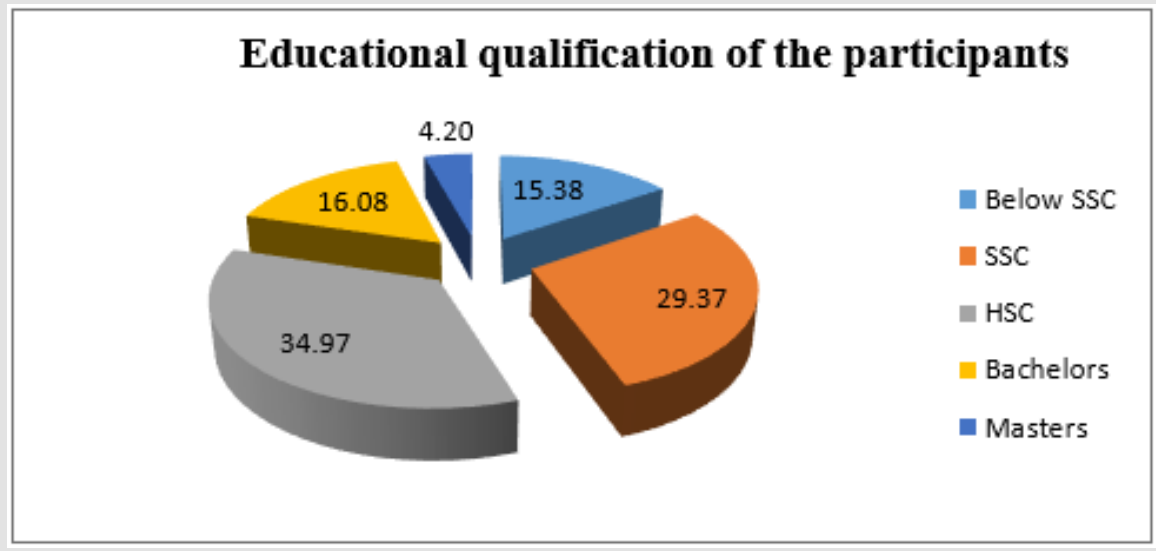

Figure 2: Distribution of the educational qualification of the participants.

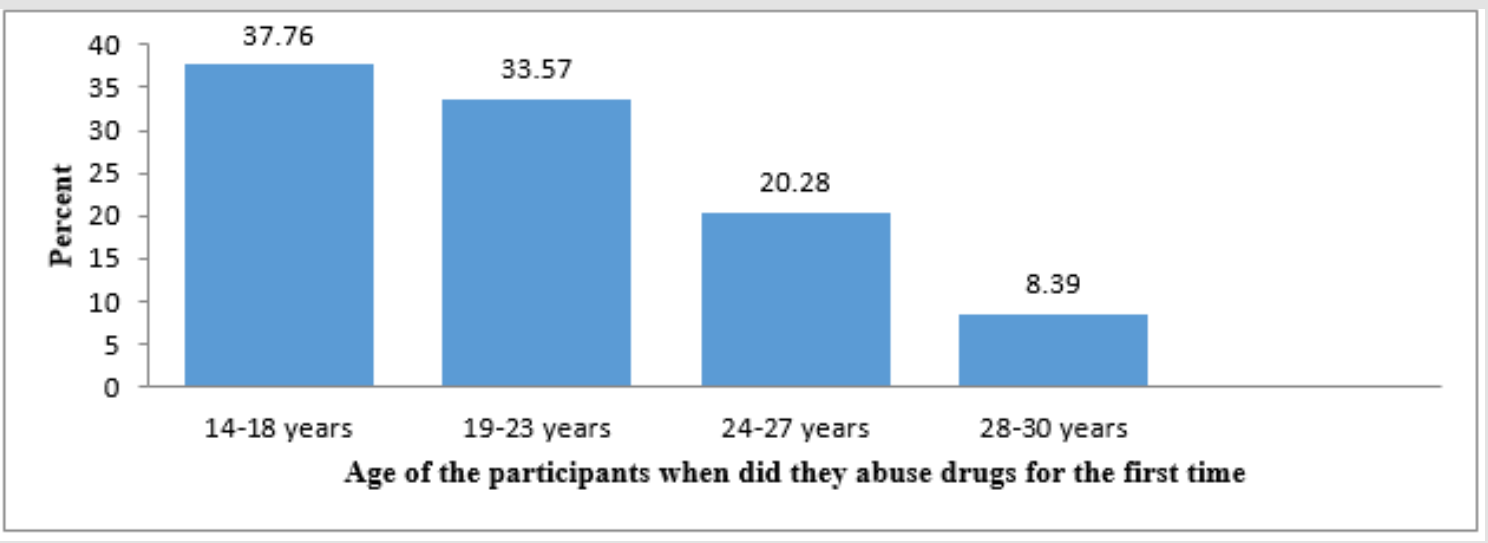

Figure 3: Distribution of age of the participants when did they abuse drugs for the first time. 
The present investigation indicates that $37.76 \%$ of the respondents abused drugs for the first time at the age of 14-18 years old, $33.57 \%$ of the respondents abused drugs for the first time at the age of $19-23$ years old, $20.28 \%$ were abused drugs for the first time at the age of $24-27$ years old and $8.39 \%$ were abused drugs for the first time at the age of 28-30 years old (Figure 3). (Figure 4) indicates that $16.78 \%$ of the respondents have been addict for 0-2 years, $18.89 \%$ of the respondents have been addict for 2-3 years, $38.46 \%$ of the respondents have been addict for 3-4 years and $25.87 \%$ of the respondents have been addict for more than 4 years. The analysis indicates that $44.76 \%$ of the respondents were influenced to take drugs by friends, $28.67 \%$ were by classmates, $15.38 \%$ were by relatives, $6.29 \%$ were by himself and $4.90 \%$ were influenced by others (Figure 5). According to the results, the respondents indicated that Yaba was major abused drugs in the age between 14-30 years. 31.47\% of the respondent were abused Yaba, 21.68\% were abused Phensedyl, 20.98\% were abused Cannabis (ganja), 14.69\% were abused heroin, 7.69\% were abused Sleeping pills (seduxen) and $3.49 \%$ were abused other drugs (Figure 6).

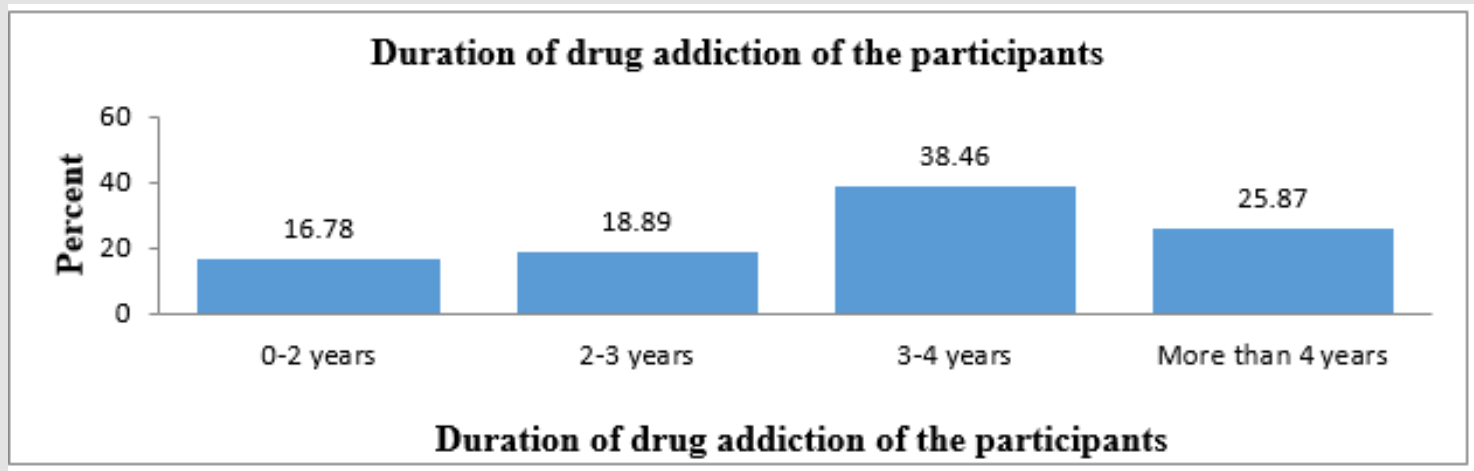

Figure 4: Distribution of the length of time of participant's taking drugs.

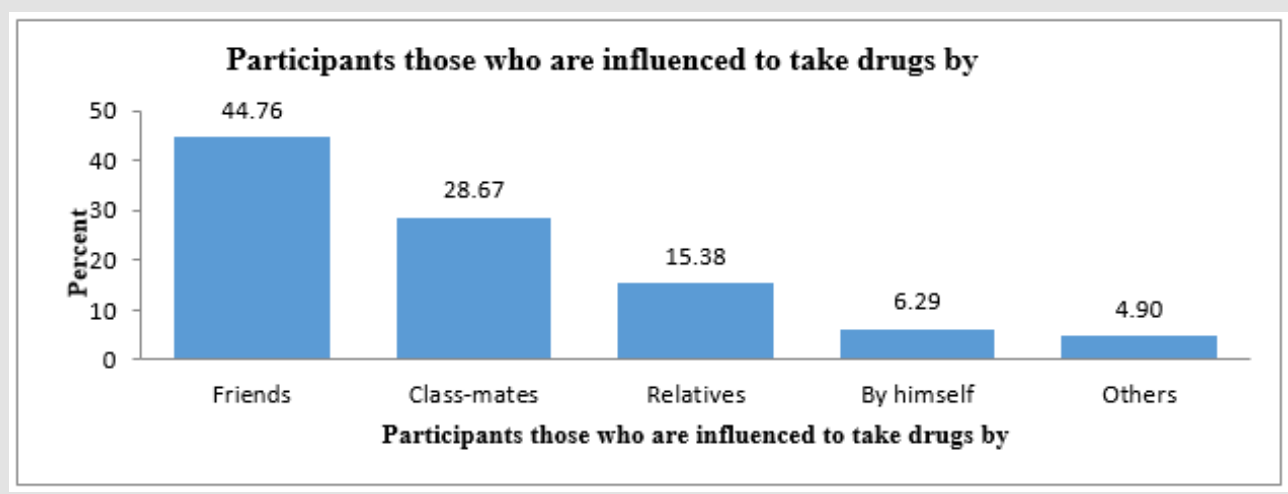

Figure 5: Distribution of participants those who are influenced to take drugs by.

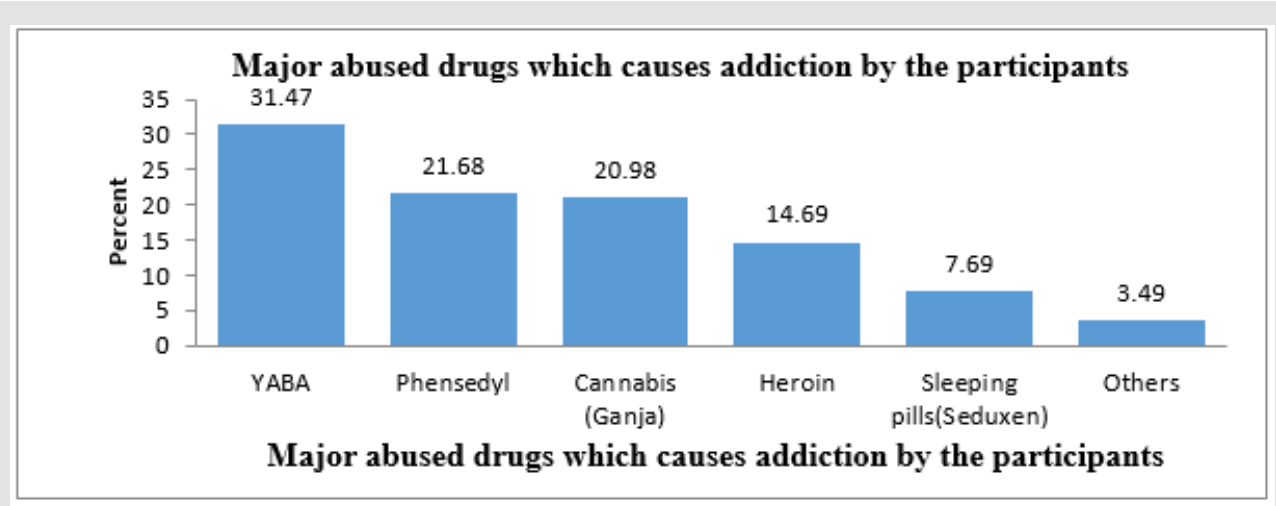

Figure 6: Distribution of major abused drugs which causes addiction by the participants. 
The analysis showed that $70.63 \%$ of the respondents abused more than one drug at the same time and $29.37 \%$ of the respondent abused only one drug at the same time. Figure 7 indicated that Yaba was major abused drugs in the age between $14-30$ years. $31.47 \%$ of the respondent were abused Yaba, 21.68\% were abused Phensedyl, 20.98\% were abused Cannabis (ganja), 14.69\% were abused heroin, 7.69\% were abused Sleeping pills (seduxen) and 3.49\% were abused other drugs. The findings summerized in (Figure 8) shows that, $27.27 \%$ of the respondent abuse drugs due to peer pressure, $21.68 \%$ of the respondents due to frustration, $16.78 \%$ due to mental stress relief, $10.49 \%$ due to curiosity, $12.59 \%$ due to build-up self-esteem \& ability to increase performance.6.99\% due to sense of euphoria, and $4.20 \%$ due to easy access or availability of drugs. The analysis showed that, $56.64 \%$ of the respondents had more than one reason of drug addiction and $43.36 \%$ of the respondent had only one reason of drug addiction.

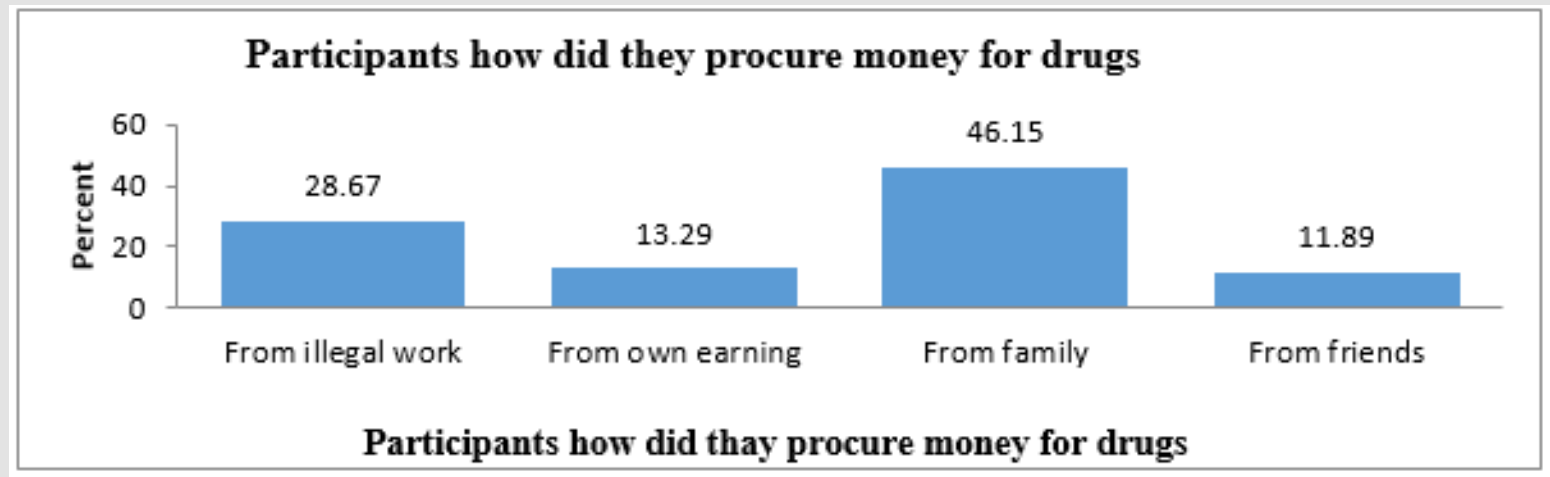

Figure 7: Distribution of participants how did they procure money for drugs.

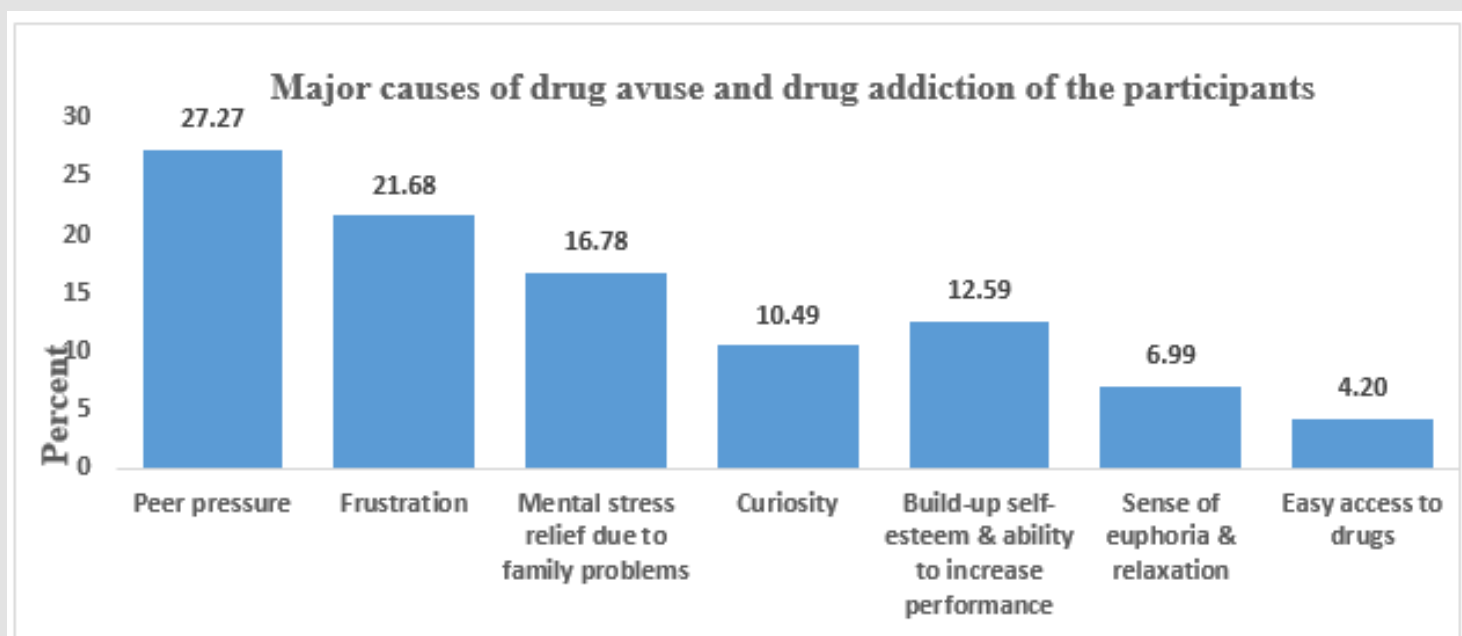

Major causes of drug avuse and drug addiction of the participants

Figure 8: Distribution of the Major causes of drug abuse and drug addiction of the participants.

The analysis showed that $28.67 \%$ of the respondent were procure money for drugs from illegal works, $13.29 \%$ were procure money from own earning, $46.15 \%$ were procure money from family and $11.89 \%$ were procure money from friends. The results on the effects of drug abuse experienced by the respondents indicate that headache, memory loss, gastritis, insomnia, bad tempered and instability were serious effects of drug abuse that the respondents experienced as expressed by the percentage of $5.59,4.90,13.29$, $32.87,20.28$ and 23.07 respectively. In addition, the study also found out that red eyes, nervousness and fatigue also have been observed due to drug abuse and drug addiction. (Figure 9) shows that $74.83 \%$ of the respondent had more than one physiological consequences and $25.17 \%$ of the respondent had only one physiological consequences. Figure 9 showed that, $29.37 \%$ of the 
respondent were encouraged to get into the rehab center by friends, $11.19 \%$ were encouraged by teachers, $44.75 \%$ were encouraged by their families and $14.69 \%$ were encouraged by their relatives. It was evident that, $27.28 \%$ of the respondent were engaged with any criminal activities but majority $72.72 \%$ of the respondent did not engaged with any kind of criminal activities. The analysis showed that, $70.63 \%$ of the respondents abused more than one drug at the same time and $29.37 \%$ of the respondent abused only one drug at the same tim.

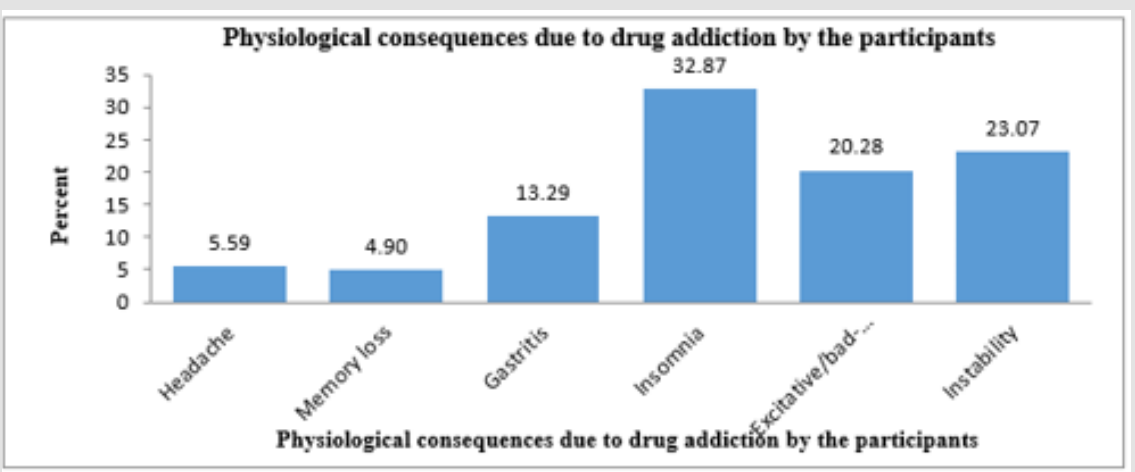

A

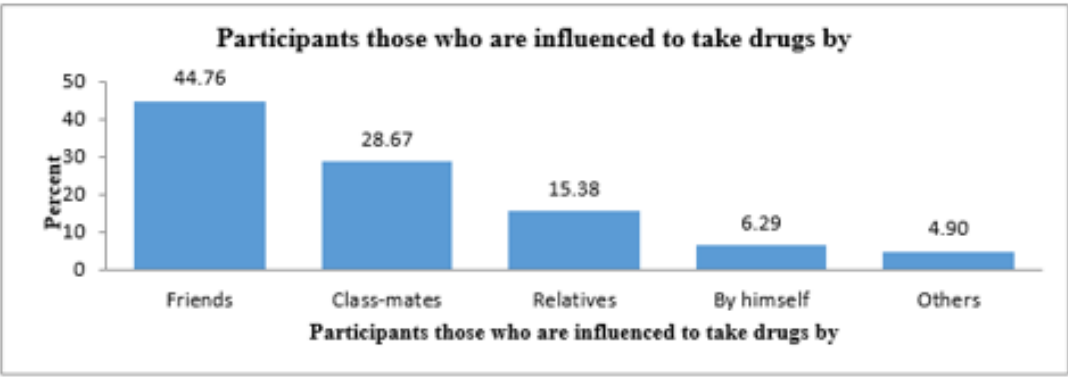

Figure 9:

A. Distribution of physiological consequences due to drug addiction by the participants.

B. Distribution of participants those who are influenced to take drugs by.

It was found that, $28.67 \%$ of the respondent were procure money for drugs from illegal works, $13.29 \%$ were procure money from own earning, $46.15 \%$ were procure money from family and $11.89 \%$ were procure money from friends (Figure 7 ). The present results reveals on the effects of drug abuse experienced by the respondents indicate that headache, memory loss, gastritis, insomnia, bad tempered and instability were serious effects of drug abuse that the respondents experienced as expressed by the percentage of 5.59,4.90,13.29,32.87,20.28 and 23.07 respectively. In addition, the study also found out that red eyes, nervousness and fatigue also have been observed due to drug abuse and drug addiction. The result of the present study showed that $74.83 \%$ of the respondent had more than one physiological consequences and $25.17 \%$ of the respondent had only one physiological consequences. (Figure 10) showed that, $29.37 \%$ of the respondent were encouraged to get into the rehab center by friends, $11.19 \%$ were encouraged by teachers, $44.75 \%$ were encouraged by their families and $14.69 \%$ were encouraged by their relatives. The third objective sought to find from respondents the likely effects of drug addiction on academic performance.

The results on the effects of drug addiction on academic performance among respondents was severe grade decades, drop out,low concentration span, discontinuation of academic career, lack of interest in extra curriculum activities and strained relationship with other students. $25.87 \%$ of the respondent had grade decades, $7.69 \%$ had drop out, $41.26 \%$ had low concentration span,9.09\% had discontinuation of academic career, $4.90 \%$ had lack of interest in extra curriculum activities and $11.19 \%$ of the respondent had strained relationship with other students (Figure 11). The analysis indicates that $28.67 \%$ of the respondent received treatment from rehabilitation centers for 1 year, $19.58 \%$ of the respondent received treatment for 2 years, $7.69 \%$ of the respondent received treatment for more than 2 years and $44.06 \%$ of the respondent received treatment for 6 months (Figure 12). 


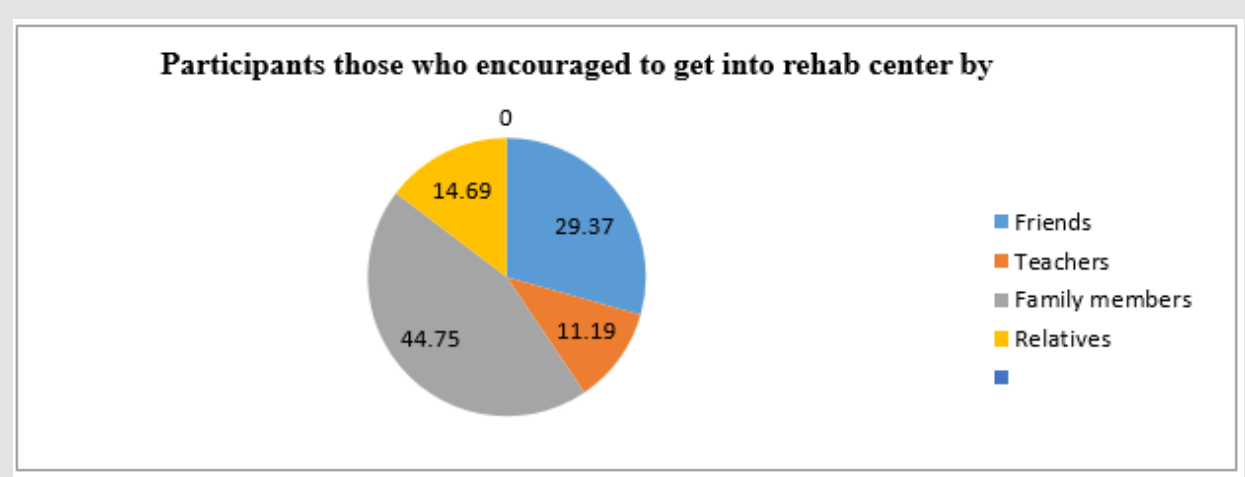

Figure 10: Distribution of participants those who encouraged to get into the rehab center by.

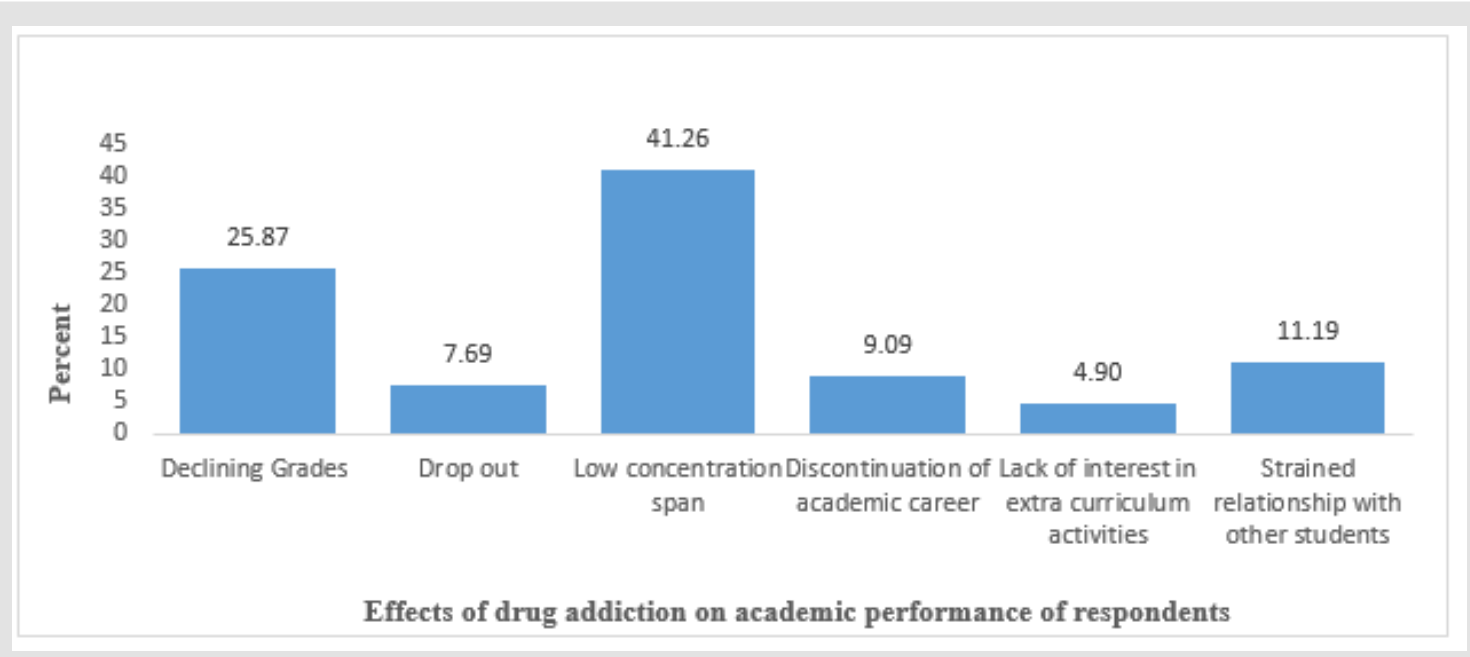

Figure 11: Distribution of effects of drug addiction on academic performance of participants.

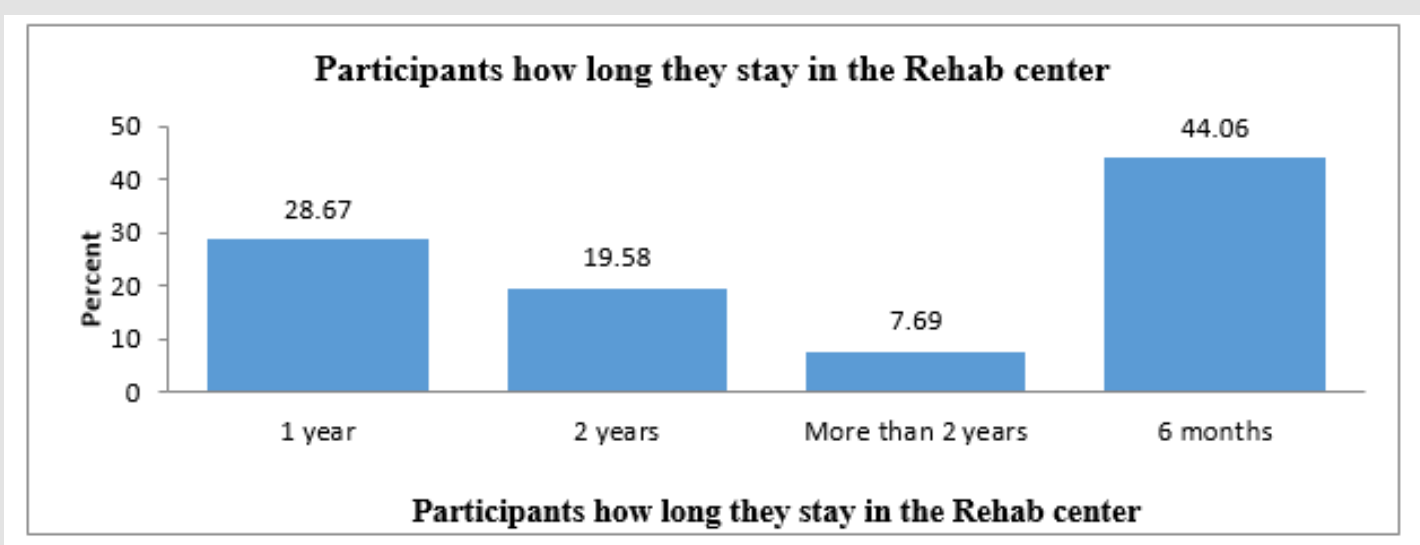

Figure 12: Distribution of the participants' period of time to receive treatment from Rehab center.

\section{Discussion}

According to Family Health International about 50 lac people of Bangladesh are drug addicted. The World Health Organization [WHO, 2003] estimates that, about 50 cror people in the world are affected by the abuse of drugs. Many of the adolescent users begin their experiment with drugs though smoking cannabis (marijuana) cigarettes, use of heroin. Typically, they begin by sniffing it (snorting) and finally injecting it intravenously (shooting the mainline) $[35,36]$. Findings on how the subjects developed their habits indicated that 50\% first took drugs through drug user friends and under pressure, $20 \%$ out of frustration and $15 \%$ out of 
curiosity. The study reports that the highest incidence of addiction occurred between 23-26 years old [37]. Due to drug addiction, criminal activities are increasing at an alarming rate all over the country, especially in urban areas like Dhaka, Chittagong, Rajshahi, Khulna, Barisal and Sylhet. The present study tries to explore the effects of drug addiction and drug abuse on academic performance of young students [38,39].

The purpose of this study was to determine the effects of drug abuse and drug addiction on Academic performance of students within age 14-30 years. The study includes the addict's students who received treatment from drug treatment and rehabilitation centers. The majority of the drug users were male even though the involvement of female was also evident. In the present study $79.72 \%$ of the respondents were males and $20.28 \%$ of the respondents were females. The present, YABA is the most frequently abused drugs by the respondents. The study also shows that $70.63 \%$ of the respondents were abused more than one drug at the same time. The study also found that, $56.64 \%$ of the respondents had more than one reason of drug addiction and $43.36 \%$ of the respondents had only one reason of drug addiction. About $27.27 \%$ of the respondents were engaged with any criminal acts [40]. The present study found that insomnia, headache, memory loss, gastritis, bad-tempered and instability were serious physiological effects of drug abuse and drug addiction of the respondents. The current study shows that drug abuse and drug addiction have adversely affected the academic performance of the respondents. Declining grades, drop out, low concentration span, discontinuation of academic career, strained relationship with other students and lack of interest in extra-curriculum activities are the adverse effects of drug addiction which directly related with academic career of the respondents.

This is in agreement with United Nations (2005) view that cognitive and behavioral problems experienced by alcohol and drug-using youth may interfere with their academic performance and also present obstacles to learning. Again drugs abused effect the brain; this result in major decline in the functions carried out by the brain. According to Abot (2005) drugs affect the student's concentration span, which is further drastically reduced setting in boredom sets in much faster than for non-drug and substance abusing students. The students who abuses drugs is likely to lose interest in schoolwork including extra curriculum activities. The study shows that the respondents were encouraged to get into the Rehab center by Friends, by teachers, by family members and by their relatives [41]. In the present study, $28.67 \%$ of the respondents stayed in the rehab center for 1 year to more than 2 years and majority of the respondents were stayed in the rehab center for 6 months. More than half of the respondents (83.22\%) were regret for their actions and (88.21\%) of the respondents want to go back to a healthy life.

\section{Conclusion}

Most of the respondents that involved in drug use and abuse fall between the age brackets of 14-23 years. Yaba is the most frequently abused drugs by the respondents. Phensedyl, Cannabis ganja, heroin and sleeping pills (Seduxen) are also abused in significant proportion. They are addicted to drugs because of the influence of peer groups, frustration, mental stress relief, curiosity. The study found out that insomnia, headache, memory loss, gastritis, bad-tempered and instability were serious physiological effects of drug abuse and drug addiction of the respondents. Drug abuse and addiction have adversely affected the academic performance of the respondents. More so, the effects of drug abuse and addiction have resulted into respondent declining grades, drop out, law concentration span, discontinuation of academic career, strained relationship with other students and lack of interest in extracurriculum activities. Government should prevent the cultivation/ sales of deadly herbs that encourage drug abuse. Government should strictly enforce its existing laws against drug abuse through its regulatory agencies [42]. Parents and guardians should endeavor to monitor their children, so that they do not engage in drug abuse. Counseling education should be introduced in campuses to revive those who have already been engaging in the act [43-57].

\section{References}

1. Gay LR (1992) Educational Research, Competences for Analysis and Application. Ohio: Charles E Merrill Publishing Co.

2. Hafiz, Rayhan (1991) Nesha Sorbonesha. Sochitro Bangladesh, p. 30.

3. Afolayan JA, Afolayan AM (2010) Drug Addiction and its academic implications among Secondary School Students in Ilorin South Local Government of Kwara State. Continental Journal of Pharmacology and Toxicology Research, p. 3.

4. Brophy JE (1988) Classroom Organization and Management. The Elementary School Journal 83(4).

5. Borg RW, MD Gall (1989) Educational Research: an Introduction. In: Borg RW, MD Gall (Eds.)., Long man Inc, New York 3(8).

6. Black John (1997) A Dictionary of Economics. In: Black John (Edt.)., Oxford University Press Inc, New York, pp. 483.

7. Akhtar BH (1991) who are the addicted? A Study of the Socio-Economic Background of Drug Addicts in Dhaka City. Centre for psycho-social Research and Training, Dhaka, p. 18.

8. Fred Leavitt (1994) Drugs and Behavior; Revised edition. SAGE, publication, pp. 536.

9. Iruloh BN, Amadi GN (2008) psychosocial perspective of drug abuse: prevention and treatment. Port Harcourt, University of Port Harcourt press.

10. Iobidz, Mariam (2009) Anti-Juvenile Delinquency policy in Georgia within the framework of the Global perspectives. Georgian Institute of Public Affairs, Department of Public Administration, p. 17-18.

11. Atah TS, Akus Y (2009) A Reading text on social studies for schools and colleges. Ankpa: Mighty word Resources Nig.

12. Akers, RL (1991) Self-control as a General Theory of crime. Journal of Quantitative Criminology. 
13. Mahdie (2016) Study the relationship between frustration tolerance and tendency to drug abuse among students from Payame Noor University, Zahedan Branch. The social sciences 11(14): 3627-3630.

14. Louw DA (2001) Human Development. Tertiary: Cape Town.

15. Moronkola OA (2003) Essays on Issues in Health, Ibadan: Royal people Nig. Ltd. NAFDAC (2008). Do Drugs Control Your Life? Know the Risks.

16. Uddin Md Jalal (2008) Addiction: Law and Practice in Bangladesh. IIUC Studies 3: 59-70.

17. Ballas P (2006) News and Features, Department of psychiatry, Thomas.

18. Njoku AO (2004) Contemporary public Issues in Social Studies Education. Enugu: Vivian; Redeemed Printing and Publishing Company. National Policy on Education (NPE) Lagos: NERDC Press.

19. Obaje SS (2009) Grounduons on social studies and Socialization Process. Ankpa: Madonna Printer

20. Williams, Wilkinss Co Perkinson, RR (2002) Chemical Dependency Counselling, California: sage publication.

21. Stephen NE (2012) Drug Abuse in.

22. Maithya RW (2009) Drug Abuse in Secondary Schools in Kenya: Development a Programme for Prevention and Intervention. Kenya: University of South Africa.

23. (1995) United Nations. The United Nations and Drug Abuse Control. UN Publication, Vienna.

24. Muyabo NW (1996) Drug Abuse. Nairobi: Uzima Press.

25. Odejide OA (1989) A Nation at Risk: Alcohol and substance Abuse and the Youths. Lagos: Republic of Kenya (2006).

26. Coleman FE (2010) drug use and Abuse Among students in Tertiary Institutions. The Case of FUT, Minna, Journal of Research in National Development 8(1).

27. Asuni T, Pela OA (1986) Drug Abuse in Africa. Bull Narc (UN Publ).

28. (2007) NACADA. Report Situation Assessment of Drug and Substance Abuse in Nairobi.

29. (2012) NACADA. A National Survey on the Magnitude of Alcohol and Drug abuse in Kenya Nairobi.

30. (1995) United Nations. The United Nations and Drug Abuse Control. UN Publication, Vienna.

31. (2005) United Nations. World Drug Report. New York: Oxford University Press.

32. (2013) United Nations (2013) World Drug Report. New York: Oxford University Press.

33. Onukwufor, Jonathan N (2016) Relationship between Parent's Drug Use, Peer Group Influence and Adolescents Addictive Behaviour. International Journal of Humanities Social Sciences and Education (IJHSSE) 3(5): 1-8.

34. Shakil, Saluddin (1985) Future uncertainty have addicted the student's. Weekly Bichitra, p. 25.

35. Khan, Hossain, Md Iqbal (1996) The Role of our Government in the prevention of Drug Trafficking and its abuse, Narcotics Central Bulletin, Ministry of Home Affairs, Dhaka, Bangladesh, p. 58.

36. Shawkatuzzaman, Syed (2003) Social Problems and Techniques of problem Analysis. Dhaka: Rohel Publications, pp. 156-159.

37. Mannan, Bashira (1996) The Everyday life of drug addicts of Bangladesh: A criticism. The Journal of Social Development, Dhaka University, p. 1-2.
38. Hossain, Md Faruque, Mamun, Mahmuda (2006) A Critical Analysis of the impact of Drug Addiction in Urban life of Bangladesh. Department of Social Work, Univeristy of Rajshahi, Rajshahi, p. 60-64.

39. Beighler F, Snowman J (1993) Psychology Applied to Teaching. Boston Houghton Mifflin Company.

40. Huq, Enamul (1985) Drug menace: Bangladesh Global perspective presented at the seminar on Anti-Drug of Asian Countries of INTERPOL Beijing. The Monthly GanaShastha, p. 34

41. Sarker, Hakim, Abdul (1991) Abuse of Drug: A steadily Growing social problem in Bangladesh. The J. Soc. Development Institute of Social welfare and Research, university of Dhaka, Bangladesh 65: 212.

42. Balswick JO, Norland JN (1991) Social Problems: Use of Illegal Drugs. Michigan Baker Book house.

43. Adler, Freda, Mueller, Gerhard, Laufer, et al. (1991) Criminology. In Adler, Freda, Mueller, Gerhard, Laufer (Eds.)., Mc Graw Hill Inc, New York pp. 124-125.

44. Annie W, Howard W, Mildred M (1996) Achievement and Ability: Test. Definition of the Domain, Educational Measurement. University Press of America. American psychiatric and statistic American psychiatric Association.

45. Amayo GN (1994) International Institute for prevention of Drug Abuse: A Handbook for Primary and Secondary Teachers' Guidelines in Drug Dependence preventive Education. Nairobi: Lama Limited Printers.

46. Bachman G, Johnstone L, Patric M, O Malley (2000) Monitoring the future National results on Adolescent Drug use: Overview of key findings.

47. Abot I (2005) Substance Use among Students and Out Of School Youth in Urban Area of Nigeria. W.H.O. Geneva.

48. Chuang, Ying Chih T, Ennett, Susan E, Bauman, et al. (2009) Relationships of Adolescents perceptions of parental and peer Behaviors with cigarette and Alcohol use in Different Neighborhood Contexts 38(10): 1388-1398.

49. Dishant, Mc Cord J, Poulin F (1999) when interventions harm: Peer groups and problem behaviour: American Psychologist 54: 755-764

50. Maithya, Redempta W (2009) Drug abuse in secondary schools in Kenya. Developing a program for prevention and intervention. Ph.D. Thesis, University of South Africa, Pretoria, South Africa.

51. Mugenda OM, Mugenda AG (1999) Research Methods: Quantitative and Qualitative Approaches. Nairobi: Acts Press.

52. Muthigani A (1995) Drug Abuse: A Rising Concern among Youth in Secondary Schools in Nairobi. Unpublished M.A Thesis, Catholic University of East Africa. Problem behaviour: American Psychologist 54: 755-764.

53. Eggert LL, Thompson EA, Herting JR, Randall BP (2001) Reconnecting Youth to prevent drug abuse, School Dropout, and Suicidal Behaviors among High - Risk Youth. Oxford United States of America.

54. Hossain, Md Anwar (2002) Juvenile Delinquency of Bangladesh and Recent thought: A criticism. Journal of Social Sciences, Rajshahi University 7: 19-25.

55. National Institute on Drug Abuse and University of Michigan. Monitoring the Future Study Drug Data Tables.

56. Obot IS (1992) The Influence of social Orientation of Predisposition of Drug Trafficking and Abuser among Youth in Ikeja LGA Lagos state. The counselor 18: 421-429.

57. Wilkinson AM (1992) The Scientist's Handbook for Writing Papers and Dissertations. Englewood Cliffs, NJ: Prentice Hall. 


\section{ISSN: 2574-1241}

DOI: $10.26717 /$ BJSTR.2021.40.006454

Md Aminur Rahman, Amina Akter. Biomed J Sci \& Tech Res

(c) (i) This work is licensed under Creative

Submission Link: https://biomedres.us/submit-manuscript.php

$\begin{array}{ll}\text { BIOMEDICAL } & \text { Assets of Publishing with us } \\ \text { RESEARCHES } & \text { - Global archiving of articles } \\ \text { - Immediate, unrestricted online access } \\ \end{array}$

